\title{
NOTE FROM THE EDITOR-IN-CHIEF
}

I am delighted to introduce the new issue of "Securitologia" (1/2018).

All the articles included in the current issue are available in English. Those written in Polish are available in two language versions.

The current issue opens with the article Diagnosing Police Activities Using Qualitative Research Methods. The author presents the possibilities of implementing qualitative research into the analyses of activities undertaken by the Polish Police, especially in the aspect of formation activities in the field of internal security of the state. The author not only proposes three ways of perceiving the Police in terms of the subject of research and description of the specifics of qualitative research but also provides suggestions of including qualitative methodology in the analysis of the Police problems.

The article Separation of Police from Citizens' Militia in the Polish People's Republic-Systemic, Organizational and Media Endeavours brings the reader closer to the changes accompanying the development of the Polish Police after the political transformation that took place in Poland in 1989. Particular attention has been paid to socio-economic turns and following changes in law enforcement agency, starting from the transformation of the name from the Militia to the Police, through staff, structural and legal reformations.

The paper Policy of the Russian Federation towards Kurds in the Syrian Conflict depicts the conditions and dependencies characterising the Russian-Kurdish relations since the beginning of the Syrian conflict. The author emphasises the role of Kurds in the Arab world and Russia's global strategy. He follows the history of the relationship between Russia and Kurds since the Persian crisis in 1946 to 1991 and the Kremlin's restraint in response to the failed Kurdish uprising in Iraq in that year. He raises the issue of Russia's return to the Middle East and its limited support for the Kurdish side in the fight against ISIS in Syria. He describes Moscow's position on the referendum in Iraqi Kurdistan that also affects the events in Syria and contributes to the further escalation of tension. He also analyses issues related to the recent offensive of the Turkish forces in the Afrin region in Syria against the Kurds.

Creating the English-language version of the journal "Securitologia" is financed under contract No. 724/P-DUN/ 2018 from the funds allocated by the Minister of Science and Higher Education for dissemination of science. 
The article Turkish Government Policy towards Independent Media after the Failed July 2016 Coup $d^{\prime}$ État presents the state of the Turkish media, as well as the actions taken by them before and after the failed attempt of the coup d'etat in 2016. Pointing to the issue of freedom of speech in Turkey, the authors highlight the numerous violations of the right to freedom of expression, which have repeatedly become part of the actions of central government authorities.

The article 'Milete min Ėid'. The Uniqueness of the Yezidi Concept of the Nation concerns the traditional Yezidi understanding of their millet, still valid, but starting to change, which is based on the mystical and metaphysical ideas incompatible with the approach preferred by contemporary political science.

In the next text Traditional Forms of Radicalism and Violent Extremism in the Western Balkans as the Main Challenge to Stability, the authors investigate the issue of radicalism and violent extremism. They analyse emerging forms of radicalism and violent extremism that exist on the territory of the Western Balkans, and their impact on the state of security in the region. They emphasise the necessity of cooperation, coordination and strategic approach among all parties of the region, for the prevention of radicalism and violent extremism in the Western Balkans.

Another paper Counter Terrorist Solutions in the Polish Police versus Contemporary Forms and Methods of Terrorist Organizations Activities was devoted to the analysis of the preparation of Polish Police counter-terrorist subdivisions to the challenges posed by the tactics used by terrorist organisations that pose a threat to national and international security.

The article The Common Good and Trust in Security Organisations draws attention to the category of trust - a component of the process mitigating the effect of the "tragedy of the commons". Its construction should be based on cooperative leadership style occurring in public organisations that work for security by shaping values, norms and patterns that cultivate the concern for the "common good".

The next text Forms of Social Pathological Changes in New Religious Movements presents forms of social pathology that can occur in destructive cult groups belonging to the category of new religious movements. The author discusses the issue of mass suicides in the historical context and the phenomenon of religious terrorism, analysing concerns aimed at ensuring the safety of citizens.

The issue ends with the article The Polish Police in the View of the Statements of the Chief Police Officers in 1990-2018 presenting the statements of the Police Chiefs during the last twenty-eight years, i.e. from its creation in 1990 to 2018 . The subject of the analysis concerns the views of the Police Authority on the functioning and organisation of the Police Service. The author of the article undertook the effort of presenting the transformation of the Police from the perspective of the opinions of the Chief Police Officers. He subjected these opinions to an evaluative analysis.

I wish all readers a pleasant and fruitful reading!

I would like to thank all the reviewers who have done their work and submitted their comments voluntarily, without any remuneration.

Editor-in-Chief Agnieszka Bukowska 